Weed Science 2018 66:226-233

(C) Weed Science Society of America, 2017

\title{
Control Recommendations for Black Medic (Medicago lupulina) Based on Growth and Development in Competition with Strawberry
}

\author{
Shaun M. Sharpe, Nathan S. Boyd, Peter J. Dittmar, Greg E. MacDonald, \\ Rebecca L. Darnell, and Jason A. Ferrell*
}

Strawberries are an important horticultural crop in Florida. Black medic is among the most problematic weeds within the production system. To better coordinate control measures, black medic growth and development while in competition with strawberry was studied. Twelve plants were randomly selected at each of four field sites in Hillsborough County, FL, in 2014. Plants were repeatedly measured over the growing season for stem length and number of primary branches, flower buds, flowers, and seed clusters. Growing degree days (GDD) were calculated $\left(T_{\text {base }}=0 \mathrm{C}\right)$ starting from the hole-punch application of the plastic mulch (October 8, 2014, to October 10, 2014) from weather station data generated from the Florida Automated Weather Network. Strawberry height and width increased consistently across all sites, but black medic growth and development varied considerably. Strawberry suppressed black medic growth up to 1,805 cumulative GDD at three of four sites where black medic remained beneath the strawberry canopy. After 1,805 GDD, the black medic stems still remained below but experienced exponential growth for total stem length and, in turn, flower buds, inflorescence, and immature seed clusters. Ideal clopyralid spray timing based on susceptible plant size was 890 to 1,152 GDD. Optimal hand-weeding time frames would likely occur as the plant stems expand beyond the strawberry canopy (to improve visibility) and before flower production to prevent seed return to the seedbank. First seed production was observed at 1,200 GDD at the earliest site and between 1,966 to 2,365 GDD across all the other sites. Overall, consistent trends were observed across sites, but betweensite variability was observed that could not be accounted for by differences in temperature.

Nomenclature: Clopyralid; black medic, Medicago lupulina L. MEDLU; strawberry, Fragaria $\times$ ananassa Duchesne.

Key words: Development, growing degree days, plant growth.

Strawberries are an economically important Florida horticultural crop with a production value of $\$ 306.5$ million in 2014 (USDA 2015). Florida strawberries are produced using a raised-bed, drip-irrigated, plasticulture system initiated with bed formation and fumigation in August. Transplants are deposited into punched holes within the bed in late September to early October, with harvest occurring from midDecember through March. Weed management is difficult due to the long growing season, and herbicides and fumigants rarely provide complete weed control from planting through harvest.

DOI: $10.1017 /$ wsc. 2017.62

First and second authors: Graduate Student and Associate Professor, Gulf Coast Research and Education Center, Horticultural Sciences Department, University of Florida, Wimauma, FL 33598; third and fifth authors: Assistant Professor and Professor, Horticultural Sciences Department, University of Florida, P.O. Box 110690, Gainesville, FL 32611; fourth and sixth authors: Professor and Professor, Agronomy Department, University of Florida, P.O. Box 11050, Gainesville, FL 32611. Corresponding author’s E-mail: sharpes@ufl.edu
According to local scientists, the most widespread and problematic broadleaf weed in Florida strawberry production is black medic (Webster 2014). Black medic emerges from the planting hole posttransplant during crop establishment. Turkington and Cavers (1979) describe black medic as an annual, biennial, or short-lived perennial that is widely distributed across temperate and subtropical regions. Black medic stems are up to $80 \mathrm{~cm}$ in length and exhibit an erect, decumbent, or prostrate habit. Black medic roots are slender yet branching and may produce dense mats of thin subsidiary roots.

Black medic competes with the strawberry crop and decreases harvest efficiency by obscuring the location of strawberry fruit. Clopyralid is a POST broadleaf herbicide registered for use in strawberries (Boyd and Dittmar 2015; Figueroa and Doohan 2006; McMurray et al. 1996); however, the label reports suppression and not control of black medic (Anonymous 2011). McMurray et al. (1996) suggested that black medic survives clopyralid application through crop shielding. Sharpe (2017) 
confirmed this and found that spray penetration through four mature strawberry cultivars only resulted in $8 \%$ coverage of water-sensitive paper placed at the planting hole. Canopy penetration is an important consideration, as there is limited translocation of clopyralid to nontreated black medic stems, as demonstrated with radiolabeled clopyralid (Sharpe 2017). Even with complete coverage, efficacy declines substantially with plant size. Black medic was adequately controlled $(60 \%$ necrosis and $90 \%$ reduction in biomass by $42 \mathrm{~d}$ after treatment) with direct application of the maximum label rate of clopyralid $\left(280 \mathrm{~g}\right.$ ae ha $\left.{ }^{-1}\right)$ when plants were small (0.5- to $1-\mathrm{cm}$ stem length), but control was reduced on larger plants (3- to 6-cm stem length) (Sharpe et al. 2016). Therefore, spray coverage and plant size are both considerations for controlling black medic growing below the strawberry canopy within the planting hole. Predicting growth and development of black medic using environmental cues easily accessible to growers will help determine application timing and implementation into production practices.

Temperature is a potential environmental predictor for plant growth due to its influence on growth and development through several physiological processes, including net $\mathrm{CO}_{2}$ assimilation and instantaneous water-use efficiency in strawberry (Kadir et al. 2006). Given the drip-irrigated plasticulture system, it is assumed water availability will not be limiting, and a viable environmental predictor for growth of black medic is cumulative growing degree days (GDD). Although the extent of the effect of temperature on the growth of black medic is largely unstudied, studies with several other leguminous plants indicate utility of temperature as a predictor. With berseem clover (Trifolium alexandrinum L.), strong linear models were developed to predict growth stages based on GDD (Clapham and Fedders 2004). For alfalfa (Medicago sativa L.) and double-cut red clover (Trifolium pratense L.), maturity dates were well predicted with GDD (Bootsma 1984).
Emergence of black medic in strawberry fields begins at 861 GDD from the hole-punch application of the plastic mulch with $90 \%$ emergence at 1,416 GDD (Sharpe 2017). Given the wide range between onset and peak emergence, it is important to understand the growth and development of black medic to best define the optimal application timing. The objective of the study was to model the growth and development of black medic in competition with strawberry using GDD from the hole-punch application to the plastic mulch to determine optimal timing for clopyralid application and hand weeding of black medic.

\section{Materials and Methods}

Black medic growth and development in competition with strawberry were investigated between November 21, 2014, and March 4, 2015. Four sites in Hillsborough County, FL, were selected (Table 1). Strawberries were grown in a plasticulture system typical for Florida production. Nitrogen was provided through drip irrigation (in the form of calcium nitrate) at: $0.34 \mathrm{~kg} \mathrm{~d}^{-1}$ then lowered to $0.23 \mathrm{~kg} \mathrm{~d}^{-1}$ at Site 1 , $0.36 \mathrm{~kg} \mathrm{~d}^{-1}$ all season at Site $2,0.68 \mathrm{~kg} \mathrm{~d}^{-1}$ then lowered (mid-November) to $0.34 \mathrm{~kg} \mathrm{~d}^{-1}$ at Site 3 , and $0.45 \mathrm{~kg} \mathrm{~d}^{-1}$ then lowered to $0.34 \mathrm{~kg} \mathrm{~d}^{-1}$ at Site 4 . Producers did not report specific dates for reduction of the fertility regime. No PRE herbicides were applied. The cultivar transplanted at all sites was 'Florida Radiance.'

Twelve plants per site were randomly selected and marked, irrespective of growth stage. Plants were between the 1- and 10-leaf stages at the beginning of the project. Plants at different growth stages were considered to account for the natural variability in the population. This was done to predict when the early-emerging plants within the strawberry field required control. Several plant traits were repeatedly measured: branch number, branch length, flower bud, and flower and seed cluster number. Only primary branches were considered for both branch

Table 1. Specifications for black medic emergence trial sites conducted in Hillsborough County, FL. ${ }^{a}$

\begin{tabular}{|c|c|c|c|c|c|}
\hline Site & GPS coordinates & Distance to weather station & Soil type $^{b}$ & $\mathrm{pH}$ & Organic matter \\
\hline & & $\mathrm{km}$ & & & $\%$ \\
\hline 1 & $28.09^{\circ} \mathrm{N}, 82.16^{\circ} \mathrm{W}$ & 10.95 & Lake fine sand & 7.3 & 1.4 \\
\hline 2 & $28.08^{\circ} \mathrm{N}, 82.19^{\circ} \mathrm{W}$ & 8.17 & Ona fine sand & 6.8 & 1.2 \\
\hline 3 & $27.94^{\circ} \mathrm{N}, 82.18^{\circ} \mathrm{W}$ & 9.25 & Zolfa/Myakka fine sand & 6.3 & 1.4 \\
\hline 4 & $27.97^{\circ} \mathrm{N}, 82.20^{\circ} \mathrm{W}$ & 6.28 & Fort Meade loamy Fine/Seffner fine sand & 6.5 & 1.0 \\
\hline
\end{tabular}


number and branch length. A primary branch was identified as originating from the initial nodes set by the plant after emergence in the planting hole and grew outward toward the strawberry canopy edge (Figure 1). These branches were designated as primary not because of the time series in which they developed but by their origin at the planting hole located on the initial stem material, which was characterized by a short intermodal stem region that developed shortly after emergence, contained leaves at the nodes, and was closest to the root system. Typical of plants that demonstrate indeterminate growth habit, primary branches would develop secondary branches along their lengths, but these data were not collected. Plants were also assigned to categories, over four timings, depending on their size: small ( 1 to 9 leaves), medium (0.5- to $5-\mathrm{cm}$ stem length), large (6- to 40-cm stem length) and very large ( $>40-\mathrm{cm}$ stem length). This information was compiled to demonstrate the proportion of each plant size over time within the population and how it changed with time.

Temperature data were collected from the Florida Automated Weather Network (University of Florida, Institute of Food and Agricultural Sciences). The station in Dover, FL, was selected due to its proximity to the field sites (6 to $11 \mathrm{~km})$. Cumulative GDD were calculated by:

$$
\mathrm{GDD}=\sum_{i=1}^{n}\left(T_{\text {mean }}-T_{\text {base }}\right)
$$

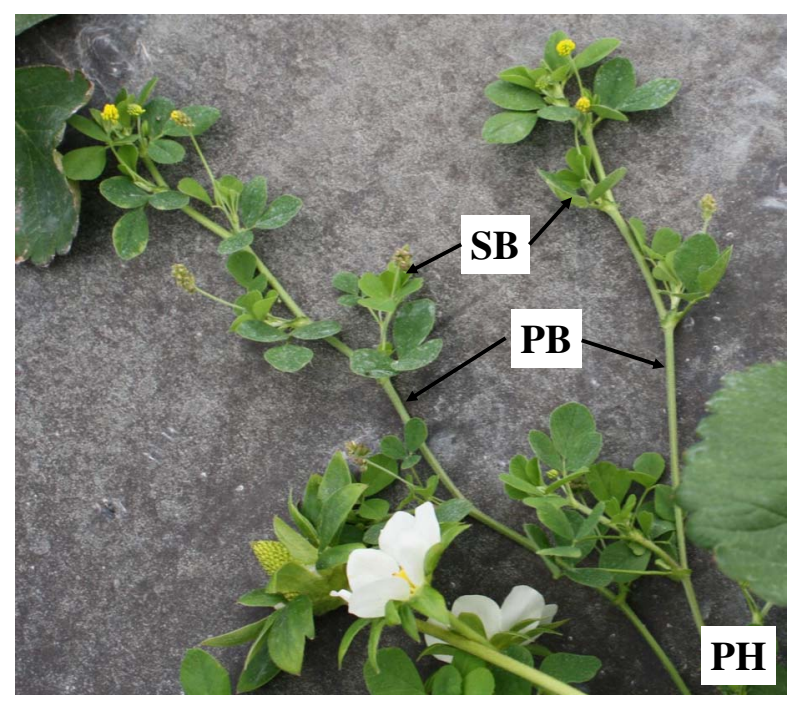

Figure 1. Demonstration of the black medic growth habit. The primary $(\mathrm{PB})$ and secondary $(\mathrm{SB})$ branches originate at the planting hole $(\mathrm{PH})$, grow along the black plastic mulch, and radiate outward. The strawberry crop is present at the planting hole. where $T_{\text {mean }}$ is the mean daily air temperature, $T_{\text {base }}$ is the lowest temperature at which growth was assumed not to occur $(0 \mathrm{C})$, and $n$ is the number of days in which GDD were calculated (White et al. 2012). GDD were calculated as starting when holes were punched in the plastic mulch and transplanted with strawberries.

Strawberry height and width and black medic stem length were modeled using the quadratic equation of the form:

$$
y=y_{0}+a x+b x^{2}
$$

where $a$ and $b$ are shape parameters. Model goodness of fit was determined using the coefficient of determination $\left(\mathrm{R}^{2}\right)$ and the adjusted coefficient of determination $\left(\mathrm{R}_{\text {adj }}^{2}\right)$ :

$$
\mathrm{R}^{2}=1-\frac{\sum\left(y_{\text {obs }}-y_{\text {pred }}\right)^{2}}{\sum y_{\text {obs }}}
$$

and

$$
\mathrm{R}_{\mathrm{adj}}^{2}=1-\frac{n\left(1-\mathrm{R}^{2}\right)}{n-p}
$$

where $y_{\text {obs }}$ and $y_{\text {pred }}$ are the observed and predicted values of the model, respectively, $n$ is the number of observations, and $p$ is the number of model parameters (White et al. 2012).

Given differences between sites, the longest black medic stem length was modeled separately. Black medic stem-length models were used simultaneously with the strawberry width model, adjusting for half the width, to determine black medic growth in relation to strawberry based on GDD accumulation. Distances of interest included: $50 \%, 75 \%$, and $100 \%$ to the strawberry canopy edge (Table 2 ). This method took into account the size of the strawberry at any given time. Models were fit to the data using

Table 2. Estimated black medic growth progression in relation to strawberry width in Hillsborough County, FL. ${ }^{a}$

\begin{tabular}{lcccc}
\hline & \multicolumn{4}{c}{ Site } \\
\cline { 2 - 5 } Black medic growth progression & 1 & 2 & 3 & 4 \\
\hline & \multicolumn{4}{c}{ GDD $^{\mathrm{a}}$} \\
\cline { 2 - 5 } $50 \%$ to canopy edge & 1,160 & 2,103 & 2,028 & 1,802 \\
$75 \%$ to the canopy edge & 1,247 & 2,278 & 2,250 & 1,967 \\
$100 \%$ to the canopy edge & 1,388 & 2,464 & 2,485 & 2,128 \\
\hline
\end{tabular}

\footnotetext{
${ }^{a}$ Both strawberry width and black medic stem length estimated by their models using growing degree days (base $0 \mathrm{C}$ for each model). GDD accumulation began at hole-punch. The strawberry width model is found in Figure 2 and the black medic stem-length models in Figure 3. Abbreviation: GDD, growing degree days.
} 
nonlinear regression in SigmaPlot (Systat Software, San Jose, CA).

\section{Results and Discussion}

Strawberries displayed similar growth rates across all sites for plant height and width (Figure 2). The strawberry plant height quadratic model predicted a maximum of $22 \mathrm{~cm}$ at 1,779 GDD (January 18, 2015). The strawberry plant width quadratic model predicted a maximum of $38 \mathrm{~cm}$ at 1,857 GDD (January 22, 2015). Assuming the strawberry plant circumference was approximately circular, distance
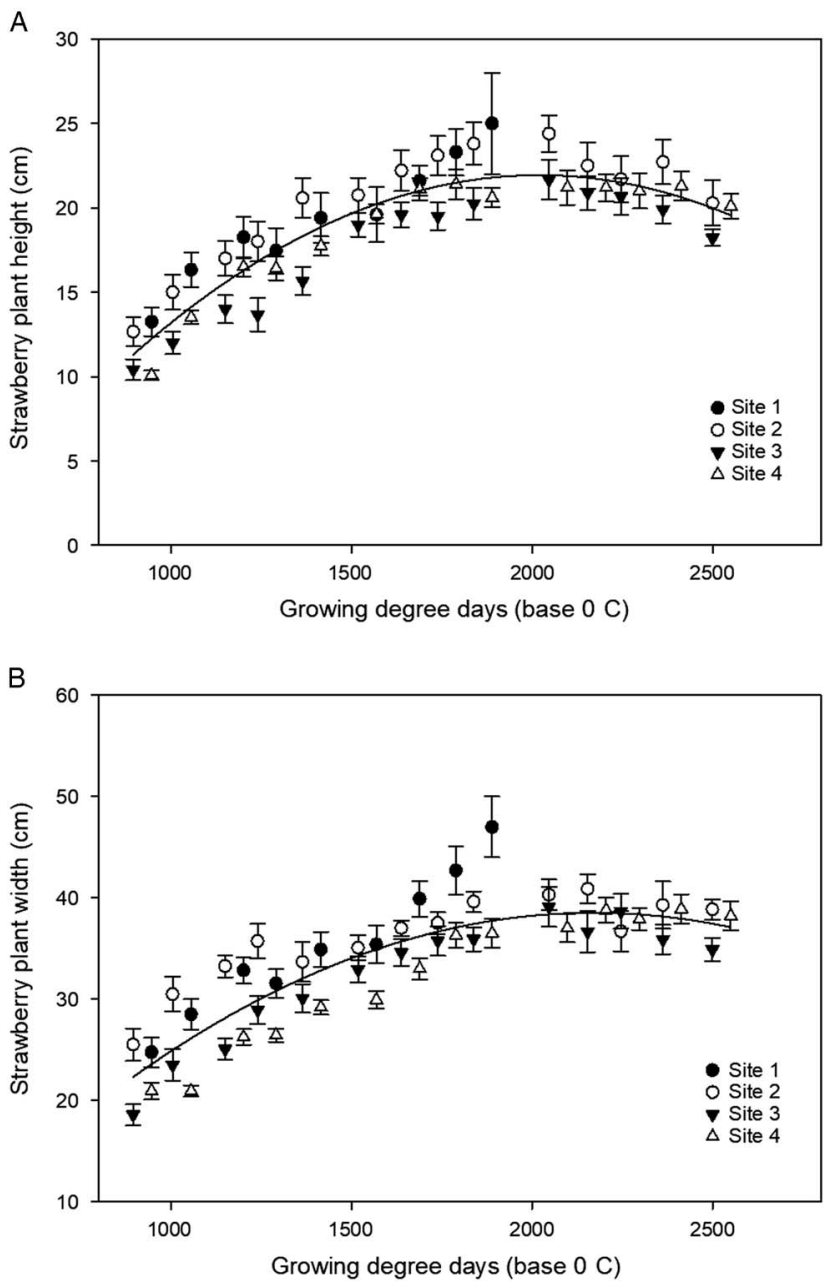

Figure 2. Strawberry plant heights (A) and widths (B) while growing in competition with black medic at four field sites in Hillsborough County, FL. Symbols represent the mean plant heights or widths; each symbol type represents a different field site; and error bars represent SE. The lines are the predicted plant heights or widths. The model for plant heights $\left(R_{\text {adj }}^{2}=0.9696\right)$ was:

$y=-12.3548+0.034 x-\left(8.41 \times 10^{-6}\right) x^{2}$,

while the model for plant widths $\left(\mathrm{R}_{\mathrm{adj}}^{2}=0.9764\right)$ was: $y=-8.3914+0.0432 x-\left(9.96 \times 10^{-6}\right) x^{2}$. from the planting hole to the canopy edge for fully matured plants was $19 \mathrm{~cm}$.

Contrary to strawberry, black medic growth and development was inconsistent across all sites (Figures 2 and 3). Differences in sites were likely not due to $\mathrm{pH}$, which varied slightly between sites (Table 1) but was well within limits reported for black medic growth (6.5 to 7.8) (Dale et al. 1965). Fertility across the sites was inconsistent and likely contributed to some of the observed variability. The addition of nitrogen to potted alfalfa did significantly alter the root to shoot ratio and shoot, root, and total biomass, but the increase or decrease was dependent on the mycorrhizal species present (Liu et al. 2017). Further study is required to determine the influence of fertility and mycorrhizal associations on black medic growth and development in strawberry production.

Once black medic emerged, its growth habit was characterized by the production and development of leaves and a short lateral branch in a compact arrangement at the planting hole (Figure 3). The shoot then produced branches from nodes close to the soil surface. Once primary branches developed at the planting hole, they elongated, and secondary branches developed along the lengths of the primary branches (Figure 1). Over the course of the growing season, tertiary branches developed from the secondary branches. Data from the secondary and tertiary branches were not collected, and only data from the primary branches will be presented. As the growing season progressed (by December 23, 2014), there was a wider disparity in growth stages, with $20 \%$ in the large (6- to $40-\mathrm{cm}$ stem length) and $10 \%$ in the very large category $(>40-\mathrm{cm}$ stem length) (Figure 4). This disparity continued throughout the growing season, but some of the larger plants were removed accidentally during harvest.

All sites demonstrated similar black medic stem elongation patterns, but the onset of elongation varied. Black medic grew substantially faster and outgrew the strawberry canopy at Site 1, undergoing exponential stem elongation earlier (Figure 3; Table 2). This may be due to the lower nitrogen rate applied at the site, which may have given the leguminous black medic a competitive advantage. The time to the onset of exponential stem elongation for black medic may be due to light competition at the planting hole or developmental timing for root and shot growth to support exponential growth, and further study is required. There were no differences in the study sites for emergence (Sharpe 2017), and 

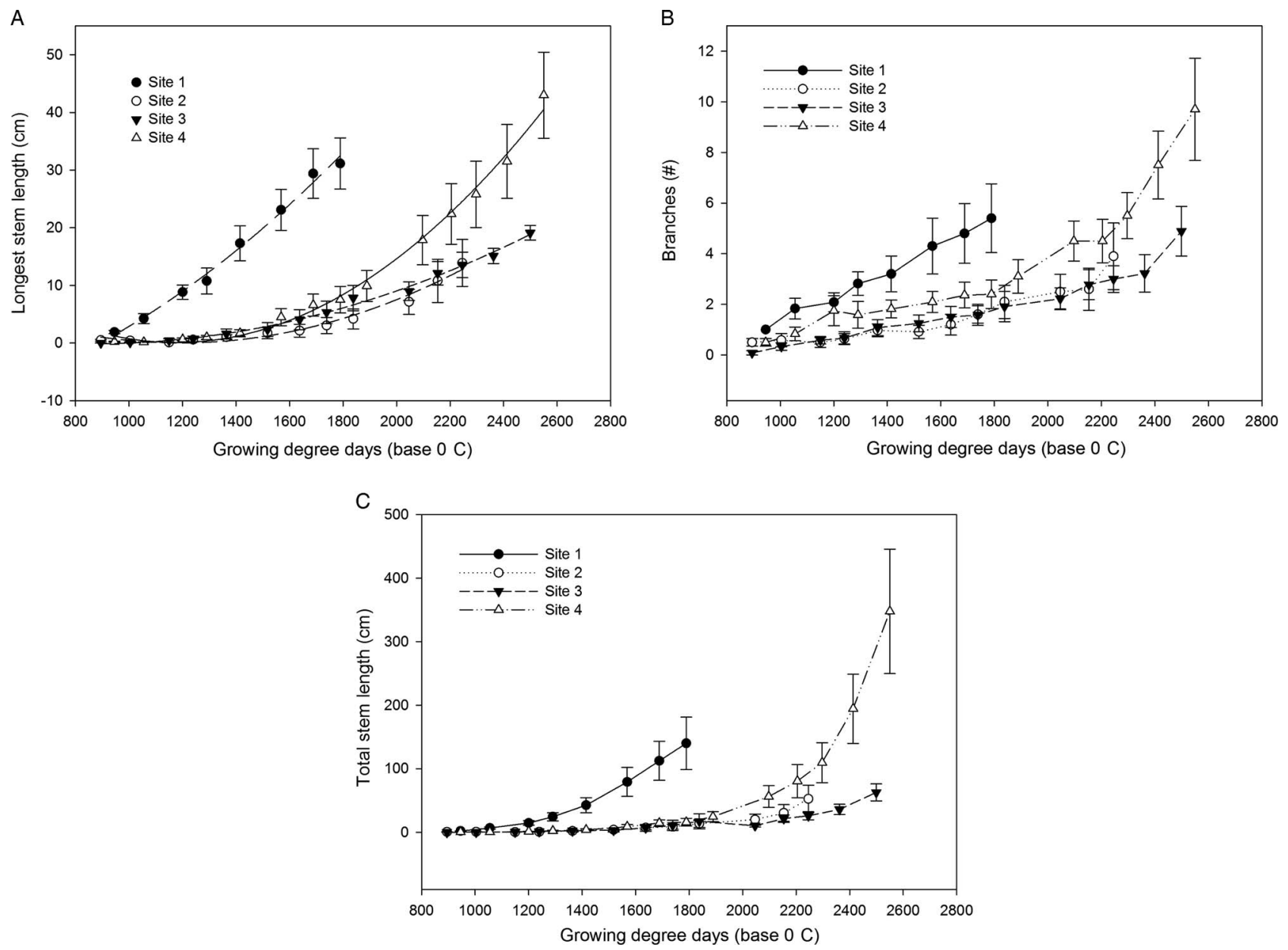

Figure 3. The length of the longest black medic stem (A), the number of branches (B), and the total stem length of all main black medic branches $(\mathrm{C})$ produced while growing in competition with strawberry in a plasticulture system across four sites in Hillsborough County, FL. Symbols represent the mean value; differing symbols represent different sites. The lines in A represent the predicted stem length, while the lines in $\mathrm{B}$ and $\mathrm{C}$ are simply point-to-point connections. A primary branch was identified as originating from the initial nodes set by the plant after emergence in the planting hole. The model for black medic stem length at Site $1\left(\mathrm{R}_{\text {adj }}^{2}=0.8146\right)$ was:

$y=-13.0698+0.0039 x+\left(1.2 \times 10^{-5}\right) x^{2}$,

the model for Site $2\left(\mathrm{R}_{\text {adj }}^{2}=0.4861\right)$ was: $y=16.2789-0.0273 x+\left(1.15 \times 10^{-5}\right) x^{2}$,

the model for Site 3 ( $\left.\mathrm{R}_{\text {adj }}^{2}=0.7730\right)$ was: $y=5.0623-0.0121 x+\left(7.05 \times 10^{-6}\right) x^{2}$,

and the model for Site $4\left(\mathrm{R}_{\text {adj }}^{2}=0.7131\right)$ was: $y=29.7598-0.0504 x+\left(2.14 \times 10^{-5}\right) x^{2}$.

transplanting for Sites 2 and 3 was $2 \mathrm{~d}$ after Sites 1 and 2.

Sites 2, 3, and 4 demonstrated a consistent trend in stem length after 1,805 GDD. At 1,805 GDD, black medic reached approximately one-half the diameter of the canopy (Table 2). This corresponded to the GDD in which the maximum strawberry height and width was achieved (Figure 2). After 1,805 GDD, black medic stems experienced exponential stem elongation. A small proportion of the black medic population $(-10 \%)$ did not leave the small growth stage category and did not experience exponential stem growth (Table 2). The exponential stem growth was followed by an increase in primary branches and an exponential increase in the number of flower buds and flowers (Figure 5).

The primary branch number increased over time (Figure 3). At each site, black medic had approximately two primary branches when it reached $50 \%$ across the strawberry canopy and three to four when the plant reached the strawberry canopy edge (Figure 3; Table 2). This was unexpected, as crop shading induces low levels of red light, generally inhibiting lateral branching (Moe and Heins 1990). Light interception may vary across the strawberry plant, affecting light penetration and availability to black medic below; this requires further study. Alternatively, a selection pressure may exist to promote early branching while in competition 


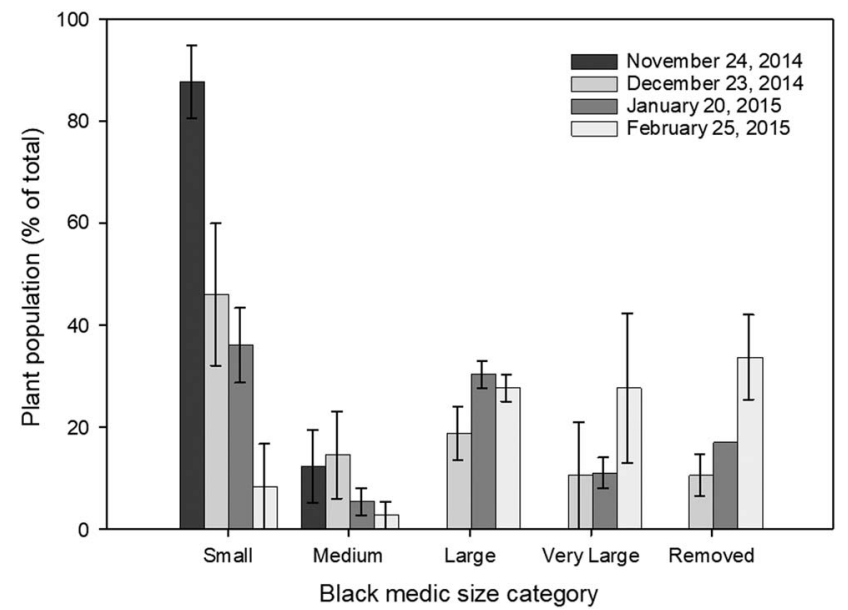

Figure 4. Histogram demonstrating mean proportions of the population $( \pm S E)$ across all four sites within four size categories of black medic. The growth stages were: small (1 to 9 leaves), medium (0.5- to 5-cm stem length), large (6- to 40-cm stem length) and very large ( $>40-\mathrm{cm}$ stem length). The removed category represents a tally of the plants that were removed during the study period. Each site had 12 plants, and the data were pooled across all sites for a total of 48 plants and expressed as a percent of the total number in each category.

with strawberry plants; this requires further study as well.

As black medic plants reached the strawberry canopy edge, black medic had approximately three to four branches (Figure 3; Table 2) and underwent exponential production of flowers (Figure 5). The onset of black medic flowering was site specific (Figure 5; Table 2) and therefore not solely influenced by temperature. The variability between sites may be due to a relationship between plant size and flowering. In New Zealand, the commencement of flowering for black medic was largely hereditary (Lammerink 1968). The strong genetic component in flowering commencement was likely due to the indeterminate growth exhibited by black medic with the production of raceme inflorescence based on size (Turkington and Cavers 1979). This was likely the case for early flowering commencement at Site 1 (increased size). Determining the timing for control measures is essential for this species to overcome recruitment to further generations.

Two control measures for emerged black medic in plasticulture strawberry are hand weeding and chemical control. Clopyralid is the only registered POST product in strawberry that is active on broadleaf weeds. Black medic plants with stem lengths between 0.5 and $1 \mathrm{~cm}$ were controlled with clopyralid when plants were directly sprayed with the high label rate $\left(280 \mathrm{~g}\right.$ ae $\left.\mathrm{ha}^{-1}\right)$ (Sharpe et al. 2016). This growth stage of black medic occurred

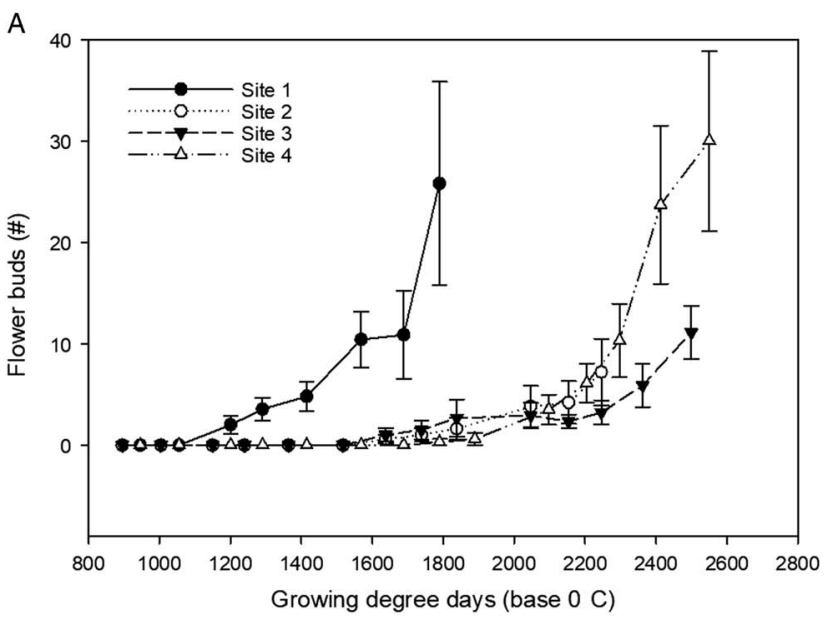

B
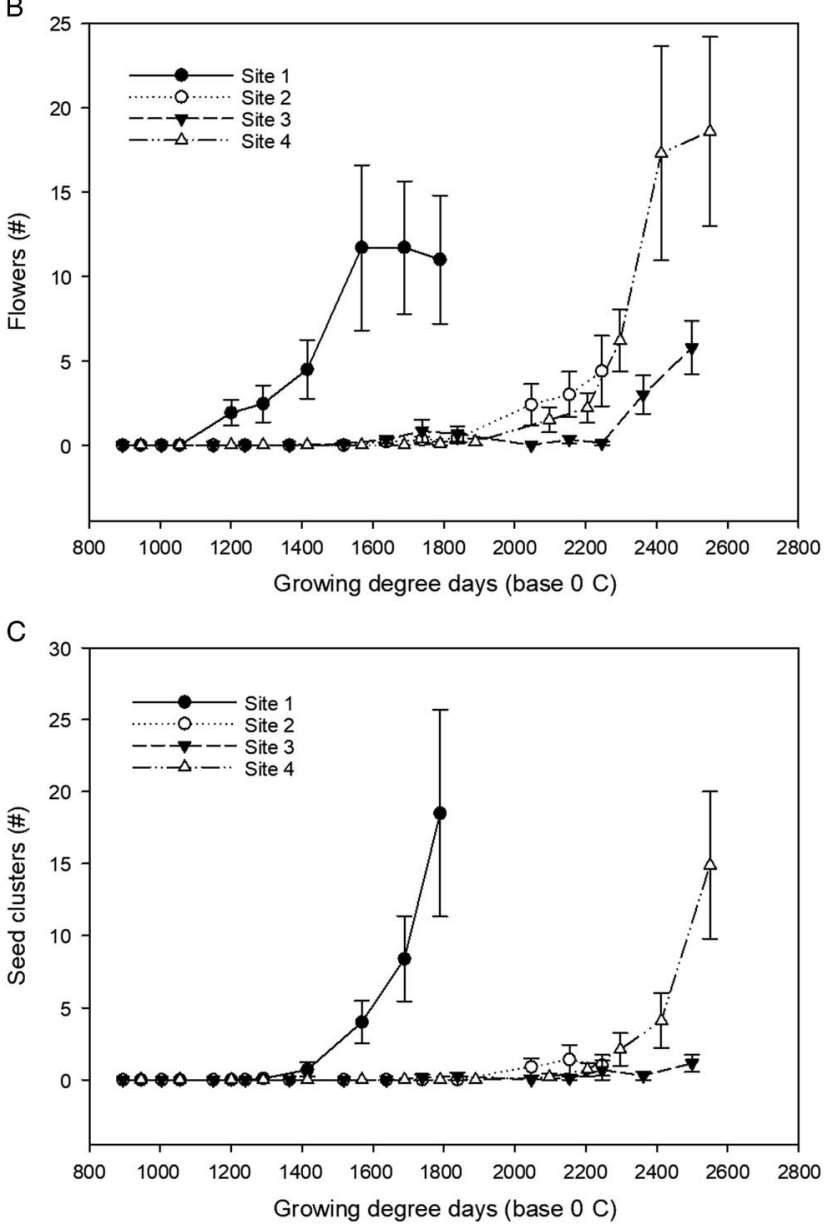

Figure 5. Number of black medic flowers buds (A), number of flowers (B), and the number of seed clusters (C) produced per plant while growing in competition with strawberry in a plasticulture system across four sites in Hillsborough County, FL. Symbols represent the mean value; different symbols represent different sites. Lines are simply point-to-point connections.

between 890 (November 23, 2014) and 1,152 GDD (December 7, 2014) across all sites (Table 3; Figure 3). These dates occur before the onset of early strawberry harvest and well before the 7 -d preharvest 
Table 3. Phenology table relating various black medic critical-control timings in both growing degree days (GDD) and yearly date for strawberry production in Hillsborough County, FL.

\begin{tabular}{|c|c|c|c|c|c|}
\hline \multirow[t]{2}{*}{ Growth stage } & \multicolumn{2}{|c|}{ Site 1 Range of Sites 2 to 4} & Site 1 & \multicolumn{2}{|c|}{ Range of Sites 2 to 4} \\
\hline & & $-\mathrm{GDD}^{\mathrm{a}}$ & & Dates__ & \\
\hline Ideal spray size ${ }^{b}$ & 940 & $890-1,152$ & November 24, 2014 & November 23, 2014 & December 7, 2014 \\
\hline First flowering & 1,200 & $1,966-2,365$ & December 8, 2014 & January 27,2015 & February 24,2015 \\
\hline First seed production & 1,416 & $2,045-2,500$ & December 24, 2014 & February 2, 2015 & March 3, 2015 \\
\hline
\end{tabular}

${ }^{\text {a }}$ GDD calculated with base $0 \mathrm{C}$.

$\mathrm{b}$ The ideal spray size refers to plants that are $<1 \mathrm{~cm}$ in stem length.

interval for clopyralid. This recommendation accounts only for the early-emerged black medic population at the initiation of the current study. Previous research found that population emergence of black medic reached $90 \%$ maximum by 1,416 GDD (Sharpe 2017). Chemical application should occur no later than the onset of flowering within the population. Evidence in pea plants (Pisum sativum L.), for example, indicates mature plant tissue exhibits increased tolerance to auxinic herbicides compared with juvenile tissue (Pazmińo et al. 2011). This suggests that for maximum control, clopyralid application should occur before the transition to mature tissue (flowering). This corresponds to 1,200 GDD at Site 1 and between 1,966 and 2,365 GDD (Table 3) at Sites 2 to 4 . The study population, which included the earliest of the emerged black medic plants at each site, had not experienced exponential growth at three of the sites (Table 3), though exponential growth was largely site dependent. Therefore, the ideal timing appears to be around $90 \%$ emergence, or 1,416 GDD (Sharpe 2017).

The second control option for emerged black medic is hand weeding. Ideal timing for black medic removal occurs before the onset of exponential growth. Removal at this growth stage prevents black medic from using available nutrition to support exponential growth yet occurs when the plants are large enough to be easily identified. This corresponded to 1,050 GDD (December 1, 2014) for Site 1 and 1,900 to 2,153 GDD (January 22, 2015, to February 9, 2015) for Sites 2 to 4 (Table 3). Strawberry fields should be hand weeded no later than the onset of flowering. First flowering initiated at Site 1 on 1,200 GDD (December 13, 2014) and 1,966 to 2,365 GDD (January 27, 2015, to February 24,2015 ) at Sites 2 to 4 (Table 3 ). Seed production initiated at 1,416 GDD at Site 1 and 2,045 to 2,500 across Sites 2 to 4 (Table 3) and increased exponentially afterward (Figure 5). During hand weeding, plants are generally pulled from the planting hole and deposited in the row middles, so care should be taken that mature seed is not left in the field. Considerations for black medic hand weeding include: (1) initiating when seedlings can be identified by the production of the first true trifoliate leaf, 2) beginning before the onset of black medic exponential growth to conserve and reduce nutrient consumption, and 3) starting before seed production to prevent reintroduction of seed into the seedbank.

Overall, strawberry plant heights and widths were consistent across all sites. Black medic stem length varied between sites. At 1,805 GDD from the hole-punch application in the plastic mulch and transplant of the strawberries, black medic reached approximately halfway across the strawberry canopy at Sites 2 to 4 . After 1,805 GDD, black medic experienced exponential total stem-length elongation followed closely by increases in flower buds, inflorescence, and subsequent immature seed clusters. Ideal clopyralid application timing for known susceptible black medic size was 890 to 1,152 GDD. For hand weeding, ideal times were between exponential growth and first flowering. Exponential growth occurred at 1,805 GDD, but varied highly between sites. The size of medic to be hand pulled should be a quarter the width of the strawberry plant. Seed production began at 1,416 GDD at the early site and between 2,045 to 2,500 GDD across the other sites. This corresponded to early February to early March, 2015 (Table 3), which is near the end of the strawberry growing season. If the system is terminated with a broad-spectrum herbicide, seed production may be reduced, though not eliminated, without additional measures needed. If the system is to be used for double-cropping, hand weeding is advisable to limit seed production and the overall rate of spread of the infestation given the elongated growing season. Given the site-specific growth patterns of black medic and the varying fates of the cropping system, scouting is recommended to form site-specific recommendations. 


\section{Literature Cited}

Anonymous (2011) Stinger ${ }^{\circledR}$ supplemental labeling for annual strawberry in Florida. Indianapolis, IN: Dow AgroSciences. $2 \mathrm{p}$

Bootsma A (1984) Forage crop maturity zonation in the Atlantic region using growing degree-days. Can J Plant Sci 64:329-338

Boyd NS, Dittmar PJ (2015) Impact of application time and clopyralid rate on strawberry growth and yield. Weed Technol 29:821-826

Clapham WM, Fedders JM (2004) Modeling vegetative development of berseem clover (Trifolium alexandrinum L.) as a function of growing degree days using linear regression and neural networks. Can J Plant Sci 84:511-517

Dale HM, Harrison PJ, Thomson GW (1965) Weeds as indicators of physical site characteristics in abandoned pastures. Can J Plant Sci 43:1319-1327

Figueroa RA, Doohan DJ (2006) Selectivity and efficacy of clopyralid on strawberry (Fragaria $\mathrm{x}$ ananassa). Weed Technol 20:101-103

Kadir S, Sidhu G, Al-Khatib K (2006) Strawberry (Fragaria x ananassa Duch.) growth and productivity as affected by temperature. HortScience 41:1423-1430

Lammerink J (1968) Genetic variability in commencement of flowering in Medicago lupulina L. in the South Island of New Zealand. NZ J Bot 6:33-42

Liu M, Sun J, Li Y, Xiao Y (2017) Nitrogen fertilizer enhances growth and nutrient uptake of Medicago sativa inoculated with Glomus tortuosum grown in Cd-contaminated acidic soil. Chemosphere 167:204-211

McMurray GL, Monks DW, Leidy RB (1996) Clopyralid use in strawberries (Fragaria $\mathrm{x}$ ananassa Duch.) grown on plastic mulch. Weed Sci 44:350-354

Moe R, Heins R (1990) Control of plant morphogenesis and flowering by light quality and temperature. Acta Hort 272:81-89
Pazmiño DM, Rodriguez-Serrano M, Romero-Puertas MC, Archilla-Ruiz A, Del Rio LA, Sandlio LM (2011) Differential response of young and adult leaves to herbicide 2,4dichlorophenoxyacetic acid in pea plants: role of reactive oxygen species. Plant Cell Environ 34:1874-1889

Sharpe SM (2017) Use of Clopyralid to Control Black Medic (Medicago lupulina) in Florida Strawberry (Fragaria $\mathrm{x}$ ananassa) Production. Ph.D dissertation. Gainesville, FL: University of Florida. $130 \mathrm{p}$

Sharpe SM, Boyd NS, Dittmar PJ (2016) Clopyralid dose response for two black medic (Medicago lupulina) growth stages. Weed Technol 30:717-724

Turkington R, Cavers PB (1979) The biology of Canadian weeds: 33. Medicago lupulina L. Can J Plant Sci 59:99-110

[USDA] U.S. Department of Agriculture (2015) National Agricultural Statistics Service. http://www.nass.usda.gov/ Data_and_Statistics. Accessed: June 19, 2015

[USDA] U.S. Department of Agriculture (2016) Soil Survey Staff, Natural Resources Conservation Service, Web Soil Survey. https://websoilsurvey.sc.egov.usda.gov. Accessed: March 30, 2017

Webster TM (2014) Weed survey-southern states 2014: vegetable, fruit and nut crop subsection. Page 288 in Proceedings of the Southern Weed Science Society 67th Annual Meeting. Birmingham, AL: Southern Weed Science Society

White SN, Boyd NS, Van Acker RC (2012) Growing degree-day models for predicting lowbush blueberry (Vaccinium angustifolium Ait.) ramet emergence, tip dieback, and flowering in Nova Scotia, Canada. HortScience 47:1014-1021

Received April 25, 2017, and approved August 27, 2017.

Associate Editor for this paper: Hilary A. Sandler, University of Massachusetts. 